\title{
Integrated Geophysical Investigation in Delineating Extent of Pollution Caused by Poultry Waste at Ilora Area, Southwestern Nigeria
}

\author{
Israel Olaoye* \\ Department of Geology, Kent State University, 800 E Summit St, Kent, OH 44240 \\ Michael Oladunjoye \\ Department of Geology, University of Ibadan, Ibadan Nigeria
}

\begin{abstract}
An integrated VLF-Electromagnetic and Electrical Resistivity survey was carried out in Odo Abata, Ilora area of Southwestern Nigeria in order to investigate the possible extent of groundwater contamination caused by an indiscriminate accumulation of poultry fecal droppings in a seasonal stream. The poultry fecal accumulation solidifies during the dry season and the percolating water plays a significant role in leachate generation and infiltration during the wet season. When in contact with the subsurface aquifer, the leachate forms a plume which diffuses into the pore spaces of aquifer with high rate of infiltration. Field data were collected using ABEM WADI VLF- EM equipment and campus Tigre Terrmeter. A total of eight VLF profiles, four electrical imaging profiles and two VES points were obtained in the vicinity of the study area. Control profiles and VES point were obtained at $500 \mathrm{~m}$ away from the study area. Field data were interpreted using KHFFilt program version 1.1a for VLF, Dipro software for electrical imaging and Winresist version 1.0 for VES data. Interpretation of VLF data showed conductive near surface layers and some fractures at depth. Electrical imaging data however revealed a near surface very low resistivity region which is due to the surface fecal accumulation. VES results showed that the overburden is clayey, and the basement is fractured. Depth to basement ranges from $9.3-12.8 \mathrm{~m}$. Poultry fecal accumulation with leachate is mostly restricted to the topmost $6 \mathrm{~m}$ of the soil and if not controlled, leachate infiltration may reach the shallow basement with time and contaminate the groundwater system of Odo Abata area.
\end{abstract}

Keywords: Very Low Frequency Electromagnetic (VLF-EM), Electrical Resistivity, Contamination, Leachate, Fracture

DOI: $10.7176 / \mathrm{JEES} / 9-10-09$

Publication date:October $31^{\text {st }} 2019$

\section{Introduction}

Groundwater is an important resource of the earth and unlike other mineral resources, it gets its replenishment from the precipitation. Groundwater contamination is a menace in our environment which occur due to heavy groundwater withdrawer and improper management of surface wastes in contact with unconfined aquifer. The recent development in the use of geophysical technique for preliminary evaluation of hazardous waste and groundwater pollution site is a quick and cost- effective means. There has been improvement in the conduct and results of groundwater pollution investigations with advancement in the resolution, acquisition and interpretation of geophysical data. Each geophysical method has advantages and limitations due to its sensitivity to the heterogenic nature of geology and a combination of two or more techniques is recommended to reduce the ambiguity in the result. A good knowledge of the local geology, site conditions and limitations of various geophysical techniques is required to select the most appropriate techniques, to design site investigation and to interpret the data acquired. One of the most commonly used geophysical technique for environmental investigation is the electrical resistivity method (Minasian, 1979). The Very Low Frequency Electromagnetic (VLF - EM) method has proven very reliable for groundwater search in basement area as a preliminary investigation technique (Amadi and Nurudeen, 1990). Benson et al (1997) employed combined resistivity and VLF methods for delineating contamination in groundwater aquifers. Olorunfemi et al (2004) used integrated VLF-EM and Electrical Resistivity survey for groundwater contamination studies in a crystalline basement complex area of Southwestern Nigeria. Moreover, Amidu and Olayinka (2006) used electrical resistivity and geochemical methods for sewage disposal assessment in Ibadan area of Southwestern Nigeria. In this work, an integrated VLF-EM and Electrical Resistivity approach was adopted in Ilora area of Southwestern part of Nigeria with a view to investigating the possible extent of groundwater contamination caused by an indiscriminate accumulation of poultry fecal droppings in a seasonal stream (Odo Abata) which flows through many poultry farms around the study area. There is no record of any geophysical work previously done on the study area to delineate polluted zones and hence this work would serve as baseline information for additional work and provide a guide to concerned government body on the remediation strategies needed for this area. 


\section{Site Description}

Odo Abata, the study area, is located in Afijio Local Government Area of Oyo State. It is bordered to the north by Jimo village and to the south by Onisa village. It is located between longitudes $3^{\circ} 50^{\prime} \mathrm{N}$ and $3^{0} 57^{\prime} \mathrm{N}$ and latitudes $8^{0} 05^{\prime} \mathrm{E}$ and $8^{0} 11^{\prime} \mathrm{E}$ (Fig.1). The area is generally rough and nearly flat with absence of rock exposures in most places. The drainage type is typically dendritic, with tributaries diverging unevenly and the flow direction is northwards. Most of the streams have dried up during the research work. The study area is situated within the rainforest belt of Nigeria, characterized by two seasons which alternate annually. The rainy season extends from April to October with mean annual rainfall ranging from 1500-2000 mm (Areola,1983). The dry season is between November and March with mean annual temperature of $21^{\circ} \mathrm{C}^{-} 30^{\circ} \mathrm{C}$. The vegetation consists mainly of rainforest trees species such as oil palm, mango and food crops like cereals, tubers etc. However, continuous human interaction with the rainforest vegetation in terms of intense land cultivation, bush burning, and land clearing for agricultural purposes is reducing the rainforest to a derived savannah. The studied stream is a seasonal stream which flows through various commercial farms, the fecal droppings from the poultry farms are discharged indiscriminately into the stream and has accumulated in the stream over years (Figs.2-3). The study area is accessible through a lateritic road that links Ilora town and Obananko community

\section{Geological Setting and Hydrogeology}

The Nigeria Basement Complex is part of the Benin-Nigeria shield located within the Pan-African mobile belts and span from the West Africa Craton to the Congo-Gabon Craton to the South-East and it is Precambrian in age. It consists of migmatites and gneisses with clear indentation of Early-Late Precambrian metamorphic events (Elueze, 1985). The basement complex has undergone several polycyclic events of major orogenies in the earth history and had its most extensive deformation and remobilization within the time of Pan - African orogeny (600 Ma) (Odeyemi, 1981).

The Migmatite-Gneiss is the most widely distributed rock in the basement complex of Nigeria. It is a heterogeneous collection of rock containing migmatites, orthogneisses, paragneisses with some ultrabasic and basic metamorphic assemblages (Rahaman, 1988).

The Basement complex of the Southwestern Nigeria lies within a later age Proterozoic belt, trending northsouth from Haggan to Gulf of Guinea. The gneisses are the dominant rocks in Ilora - Obananko area (Fig.4); they are massive in most occurrences with medium to coarse grain texture and with clear foliation bands. Most of the outcrops observed were migmatite gneiss and granite gneiss having quartz vein of varying width. The major intrusive rocks encountered are Pegmatites in form of dykes and veins, occupying the fracture zones, they are coarse in texture and weathered into sand and clay materials, which store water within the regolith layer. Structural features such as faults, joints, minor lineation and micro-folding largely control the groundwater accumulation and distribution in the area.

Davis and De West, (1966) opined that fresh basement rocks are poor aquifers because of low first-degree porosity and permeability. Therefore, the search for groundwater in the basement complex should be biased towards regions with second-degree porosity and permeability associated with fracturing and weathering of the basement rocks

\section{Materials and Methods}

Combined geophysical techniques of VLF-EM and Electrical resistivity methods were used. Field data were collected using ABEM WADI VLF-EM equipment which operates in the very low frequency range of $15-25 \mathrm{KHZ}$ and Campus Tigre Terrameter. All measurements were oriented parallel to the two major azimuths; N-S and E-W directions (Fig.7).

EM technique was first used to study the lateral variation in ground conductivity below the poultry faecal accumulated area. The ABEM WADI VLF-EM equipment measures the Real and Imaginary components of the vertical magnetic field induced as a percentage of the horizontal primary field. Eight VLF profiles ranging from 100 to $255 \mathrm{~m}$ and $20 \mathrm{~m}$ apart were established around the study area and a control VLF profile established at $500 \mathrm{~m}$ away from the study area. Filtering techniques help to improve data quality and make the tilt- angle crossovers more visible. Two filtering methods adopted in this work include the Fraser filter (Fraser, 1969) and the KarousHjelt (Karous and Hjelt, 1985). (KHFFILT Version 1.1a)

The Electrical Resistivity method involves the Wenner Electrical Imaging and the Vertical Electrical sounding. Four Electrical Imaging profile lines ranging from 40 to $300 \mathrm{~m}$ were established at the poultry fecal accumulation site with electrode spacing increasing successively by five from the first level through the last level. Four Vertical Electrical Sounding (VES) were carried out at selected locations based on the result obtained from VLF survey to delineate subsurface layers and their geoelectric parameters with electrode spacing $(A B / 2)$ varying from 1-75 m. Control Electrical imaging profile line and VES were established at $500 \mathrm{~m}$ away from the fecal dump site. DIPRO for windows (2004) software was used separately to produce the inverted section and the results compared with the results of other methods during interpretation. The inversion was run for the first five iterations. 
Partial (manual) curve matching technique and 1-D WinRESIST version 1.0 computer program were used for the interpretation of the VES data.

\section{Results and Discussion \\ VLF-EM Profiles}

The VLF data recorded in the vicinity of the study area are presented as Fraser filtering profiles and Karous- Hjelt pseudosections (Figures 8-16), the interpretation of both of which is qualitative. The Fraser and Karous-Hjelt filtering of Odo Abata profiles 1 and 2 (Figs.8\&9) corroborate each other and show that the traverse coverage area is generally moderately conductive with regions at distances $50 \mathrm{~m}, 75 \mathrm{~m}, 124 \mathrm{~m}$ and $220 \mathrm{~m}$ on profile 1 and $50 \mathrm{~m}$ on profile 2 showing high conductivity peaks and thus constituting anomaly while profile 3 (Fig.10) shows pockets of 'hot targets' distributed within the conductive region. The conductivity decreases across profiles 1 through 3 , i.e. away from the fecal accumulation. Profiles 4 and 5(Figures 11\&12) show moderately conductive regions with highly conductive zones appearing on profile 5, which is attributed to the presence of fish ponds serving as fecal accumulation zone in the vicinity of profile 5 . The high conductivity noted at distance $115-125 \mathrm{~m}$ in both Fraser filtering and Karous Hjelt pseudosection of profile 6(Fig.13) corresponds to the point of discharge of poultry waste through the channel into the centre of accumulation. Profiles 7 and 8 (Figures 14\&15) also show moderately conductive region with few anomalous conductivities between $8.0-20.0 \mathrm{~m}$ and $55.0-65.0 \mathrm{~m}$ in profile 7 which is due to the fecal accumulation. However, both Karous Hjelt pseudosection and Fraser filtering of control profile 9 (Fig.16) reveal low conductive region compared with profiles 1-8 and this is due to the absence of the fecal accumulation at the location where the control profile was run.

\section{Resistivity Inversions and Sounding Curves}

For resistivity inversion (Profiles $1-4$, Figs. 17-20), the 2-D resistivity structure shows that the surface and the near surface layers are characterized by very low resistivity values that increase with depth. The exceptionally low resistivity values (10-15 $\Omega \mathrm{m})$ are observed between station distances $46-85 \mathrm{~m}$ along profile 1 , very close to the surface in profile 2 , near the end of profile 3, near the surface and occupy about $89 \%$ of profile 4 . The control inversion (Fig.21) however reveals that the near surface layers to depth of about $10 \mathrm{~m}$ have resistivity values of about $35 \Omega \mathrm{m}$ and above as against the lower resistivity values of profiles $1-4$. The exceptionally low resistivity (highly conductive) zones observed in inverted sections 1- 4 are due to the accumulation of the poultry feces whose depth of infiltration ranges between $0-5 \mathrm{~m}$ and this corroborates the VLF results. The higher resistivity noted in the control inversion is due to the absence of poultry fecal accumulation in this zone. The basement is shallow with uneven topography. Vertical Electrical Sounding results (VES1-3, Figs.22-24) are characteristically threelayer $\mathrm{H}$ - type model, the geologic interpretation proffered are the sandy topsoil, weathered unit and partly fractured basement. The topsoil is generally very thin, the weathered unit is fairly thick in VES1 (Fig.22) and 3 (Fig.24) and has low resistivity values across the three VES. The weathered unit, which is predominantly clay and the fractured basement, constitute the aquifer in the study area.

In all, the contaminant was observed to have infiltrated to depth of about $6 \mathrm{~m}$. Since the topsoil is very thin (average thickness is $1.56 \mathrm{~m}$ ), the contaminant has infiltrated the topsoil into the clayey unit, and thus groundwater in the weathered regolith in the vicinity of the study area may have been contaminated. Regions below $6 \mathrm{~m}$ depth have low concentration of the contaminant as the concentration decreases with depth.

\section{Conclusions}

The integrated geophysical approach involving VLF-EM and Electrical resistivity methods assist in understanding the subsurface geological conditions especially in the basement complex area. In essence, the VLF-EM has revealed the presence of good conductors at depth even to the basement. Near surface conductors have been found to be regions of accumulation of the poultry fecal contaminant by Electrical Imaging while deeper conductors are fractures located at depth. Poultry fecal accumulation concentrated mostly at the topmost $6 \mathrm{~m}$ of the subsurface and if not controlled, leachate infiltration will reach the shallow fractured basement with time and may contaminate the groundwater system of Ilora area.

\section{References}

Amadi, U. M. P. and Nurudeen, S. I., 1990, Electromagnetic survey and the search for groundwater in the crystalline basement complex of Nigeria. Journal of Mining Geology, 26, $45-53$.

Amidu, S. A., and Olayinka, A. I (2006), Environmental assessment of sewage disposal systems in Ibadan area of Southwestern Nigeria. Environmental and engineering geosciences 12, 3: 261-272

Areola, O. 1983. "Soil and Vegetal Resources". In: A Geography of Nigerian Development. Oguntoyinbo J.S., et. al (ed). Heinemann Educational Books: Ibadan, Nigeria.

Benson. A.K., Payne. K.L. and Stubben.M.A.(1997). Mapping groundwater contamination using DC resistivity and VLF geophysical methods- A case study. Geophysics vol.62, no.1 
Davis, S.N., and De West, R.J.M., 1996. Hydrogeology Wiley, N.Y

Elueze, A. A.(1985):Petrochemical and petrogenetic characteristics of Precambrian Amphibolite of the Alawa district Northwestern Nigeria.

Fraser, D.C., Contouring of VLF-EM Data, Geophysics, vol. 34, no. 6, pp. 958-967, 1969.Gearhart Industries, Inc., Basic Cement Bond Log Evaluation, Fort Worth, TX, 1982

Geological Survey of Nigeria Map, 1994 edition

Karous, M. and Hjelt, S.E.,(1985). Linear Filtering of VLF Dip Angle Measurements, Geophysical Prospecting,vol. 31, no. 5, pp. 782-794.

Minasian, R. S., 1979, Prospecting for subsurface water in the central volcanic highland of Armenia by Geophysical methods. Geophysical Prospecting, Vol. 27, No. 4, Pp. 808 - 814.

Odeyemi, I. B. A review of the orogenic events in the Precambrian basement of Nigeria, West Africa runs sch., vol.3:29-41

Olayinka, A.I, Amidu, S.A and Oladunjoye, M. A (2004). Use of electromagnetic and resistivity sounding for groundwater exploration in the crystalline basement area of Igbeti, Southwestern Nigeria. Global Journal of geological sciences 2.2:243-253

Olorunfemi, M. O., Dan - Hassan, M. A. and Ojo, A. S., 1995, On the scope and limitations of the electromagnetic methods in groundwater prospecting in a Precambrian basement terrain a Nigerian case study. Journal of Africa Earth Sciences, Vol. 20 No. 2, $151-160$.

Olorunfemi, M. O Fatoba, J.O and Ademilua, L.O (2004). Integrated VLF-Electromagnetic and Electrical resistivity survey for groundwater contamination in a crystalline basement complex terrain of Southwestern Nigeria. Global Journal of Geological sciences vol.3,no.1,71-80, 2005

Palacky,G.J.,Ritsema,I.L. and DE-Jong,S.I .(1981):Electromagnetic prospecring for groundwater in Precambrian terrains in the republic of Upper Volta. Geophysical prospecting 29,932-955.

Rahaman,M.A.(1988):Recent Advances in the study of the basement complex of Nigeria, Precambrian geology of Nigeria. Publishing of the geological survey of Nigeria

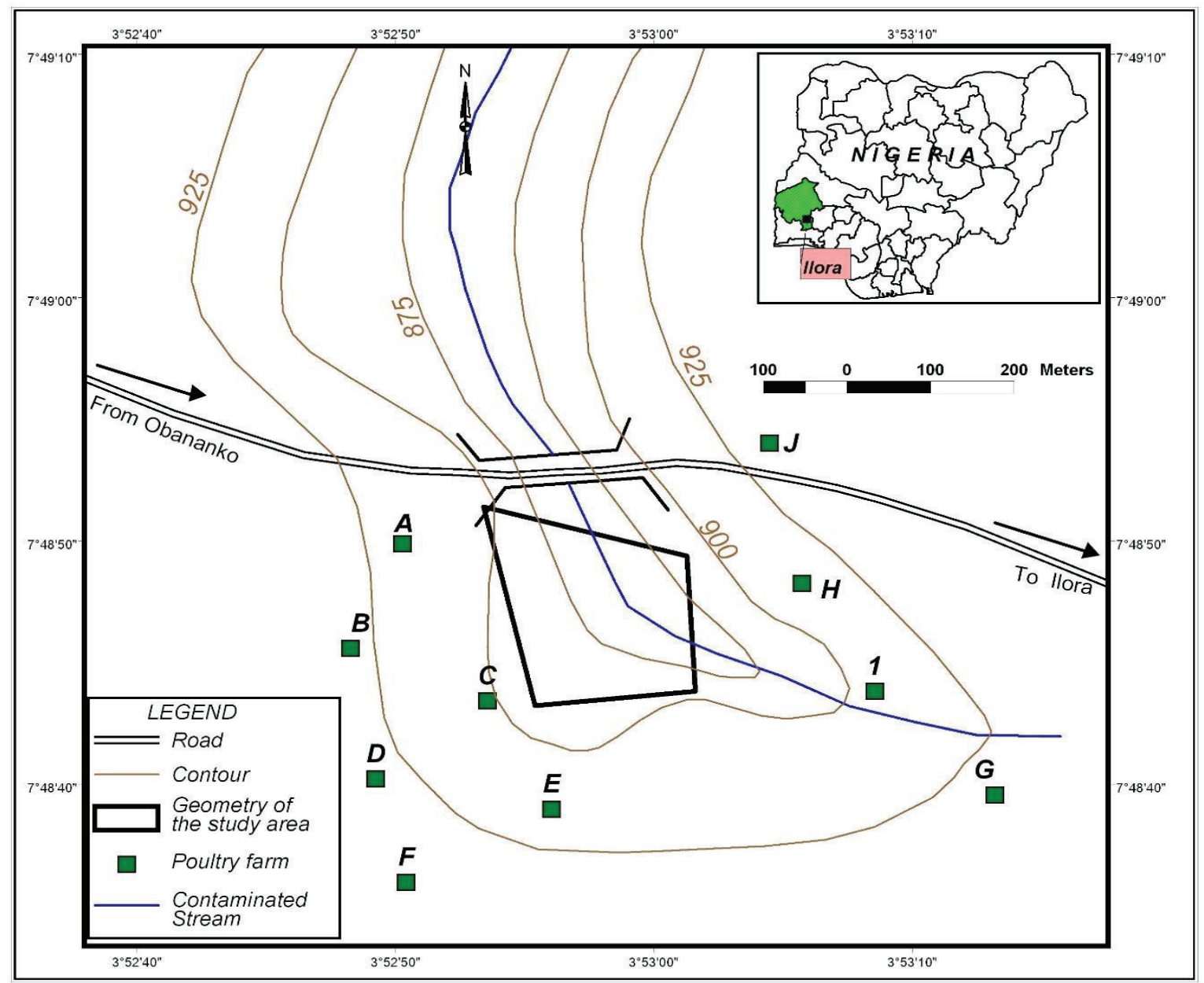

Fig.1. Location Map of Ilora showing the study area. 


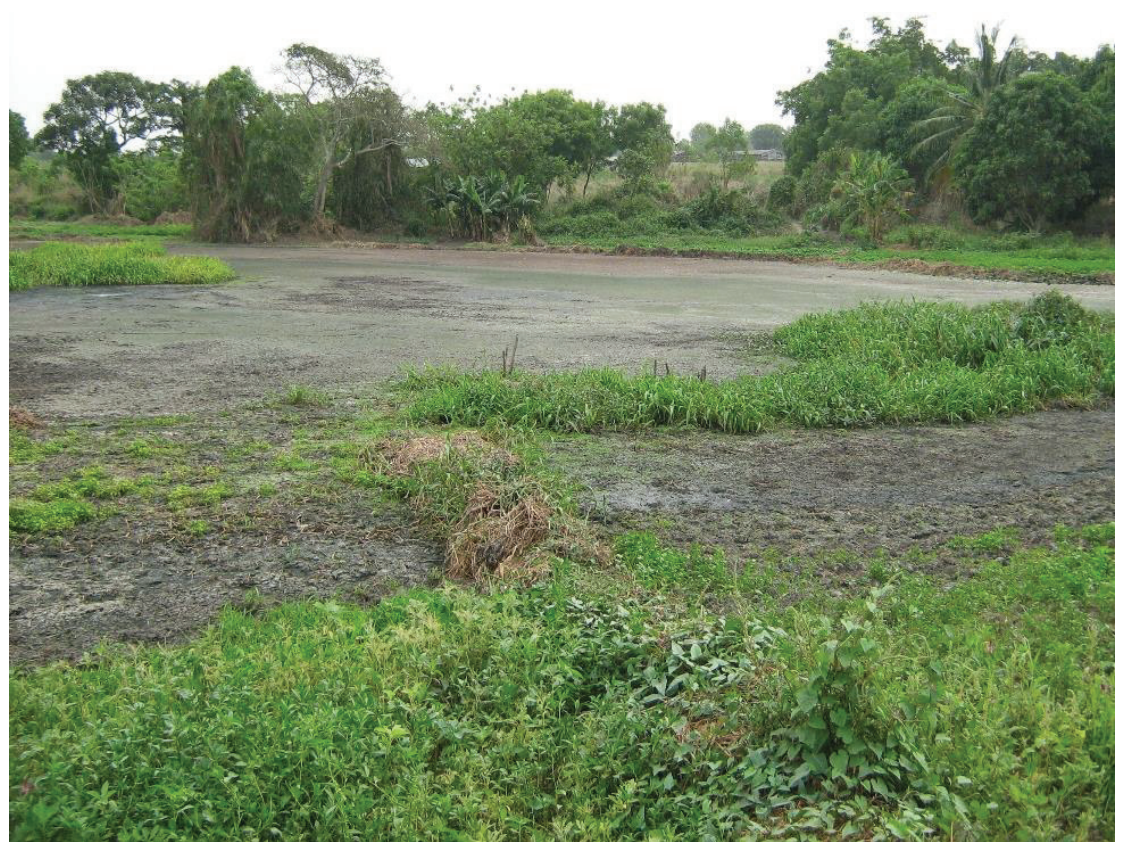

Fig.2. Accumulated fecal droppings and Plants (Wet Season).

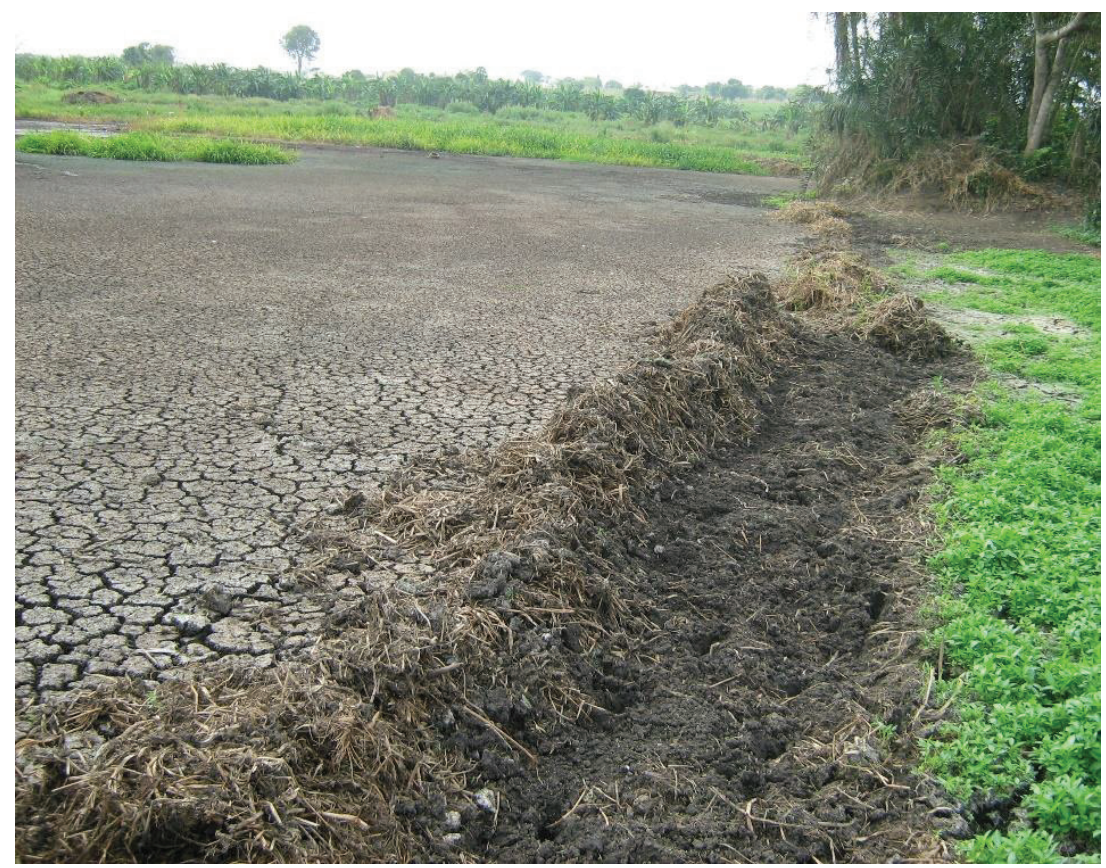

Fig.3: Poultry fecal accumulation in the stream (Dry Season) 


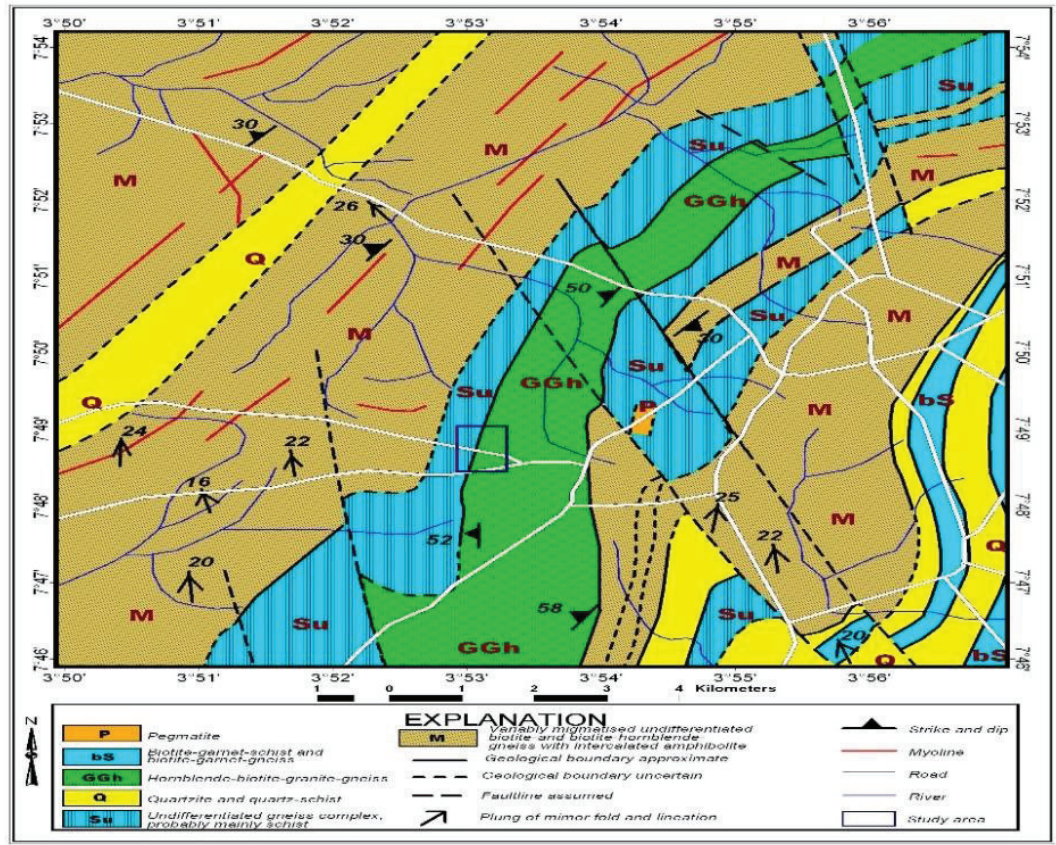

Fig.4: Geological Map of the study area (Modified after 1994 edition of the Geological Survey of Nigeria Map)

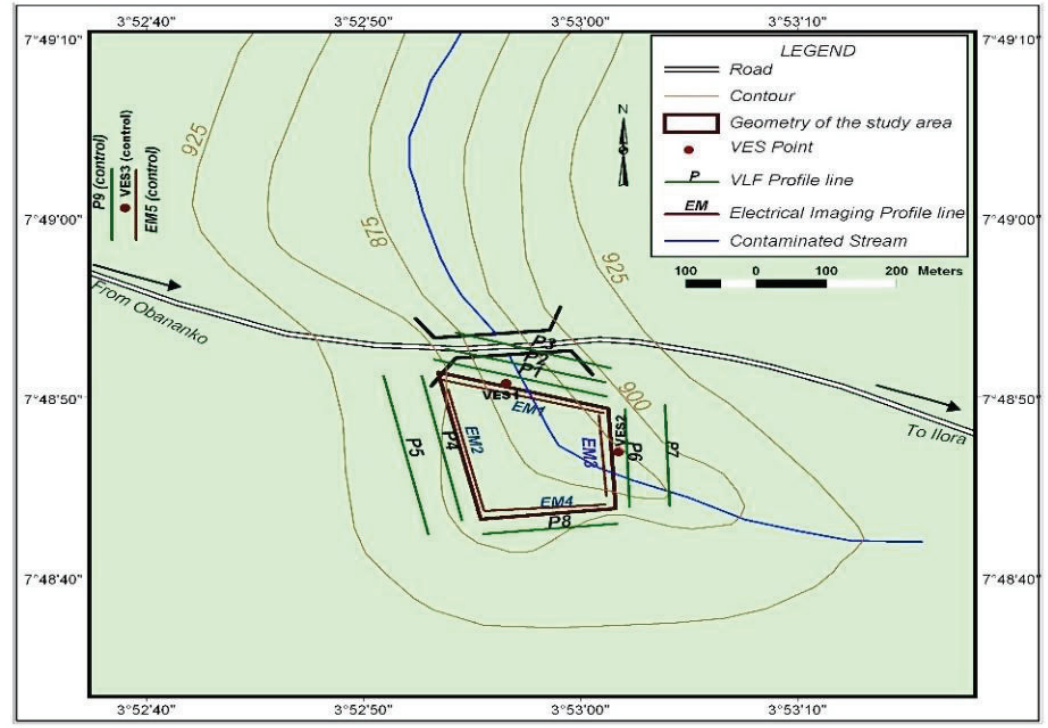

Fig.7: Geophysical data acquisition Map showing the VLF profiles, Electrical Imaging Profiles and VES stations. 
Fraser filtering
"Odo Abata, Ilora Profile
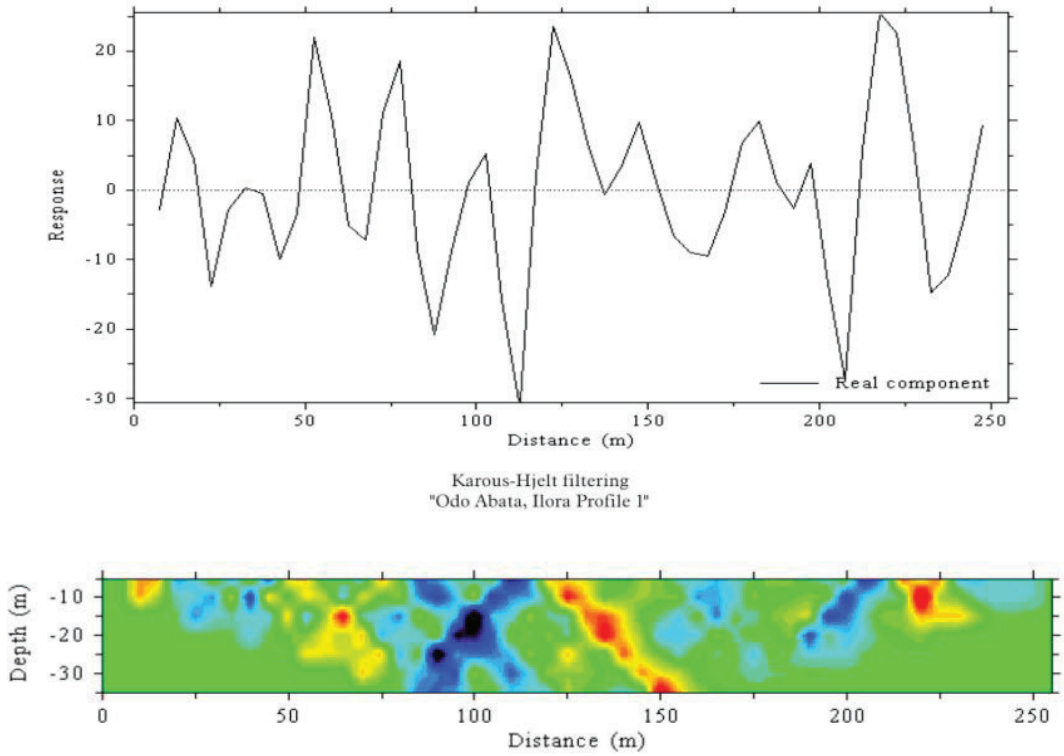

$-10$

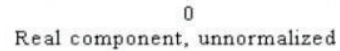

Fig. 8 :( a) Fraser filtering of Odo-Abata VLF profile 1

(b)Karous-Hjelt filtering of Odo-Abata VLF profile1

Fraser filtering
"Odo Abata, Ilora Profile 2"
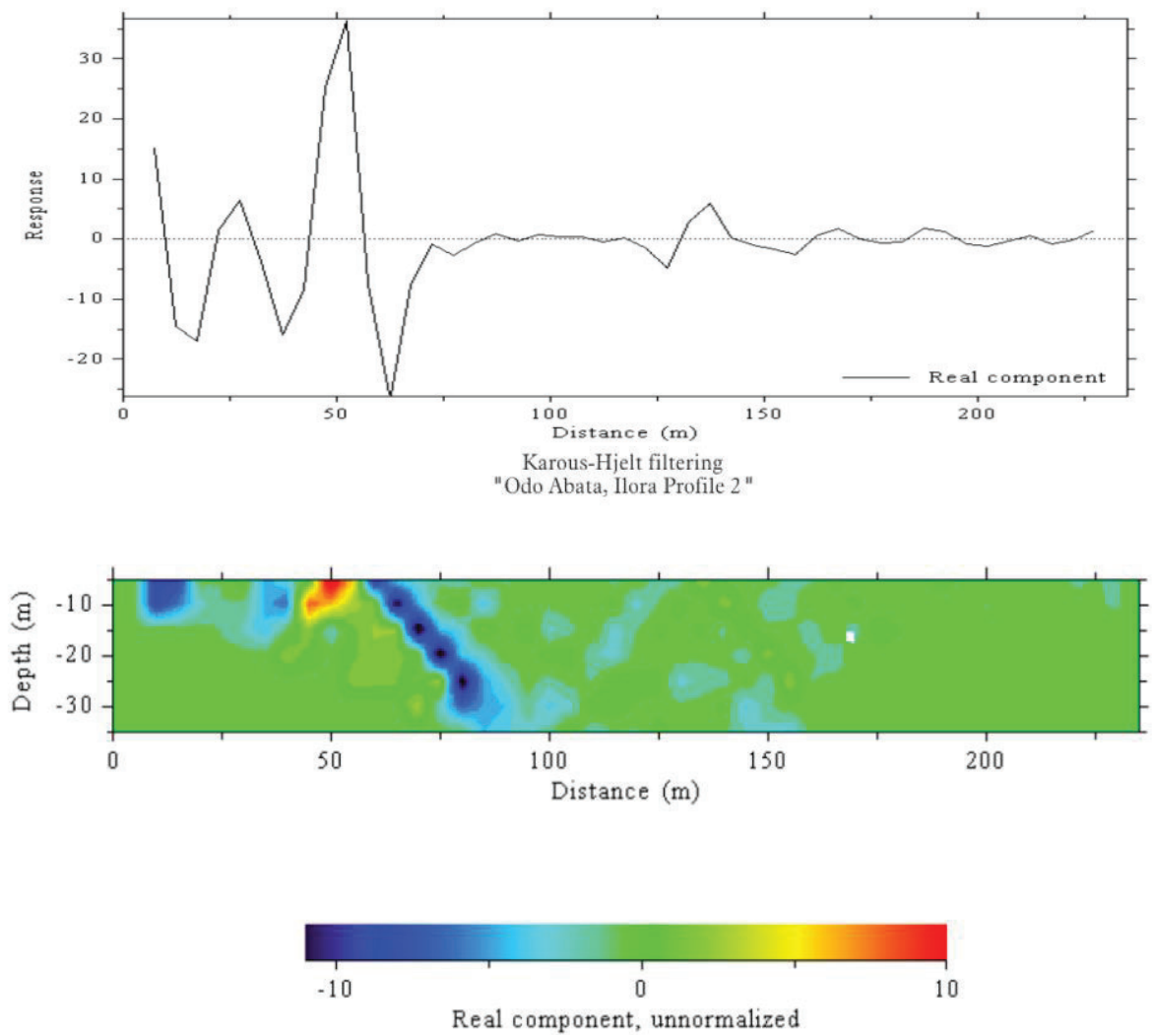

Fig.9 :( a) Fraser filtering of Odo-Abata VLF profile 2 (b)Karous-Hjelt filtering of Odo-Abata VLF profile 2 
Fraser filtering
"Odo Abata, Ilora Profile 3"

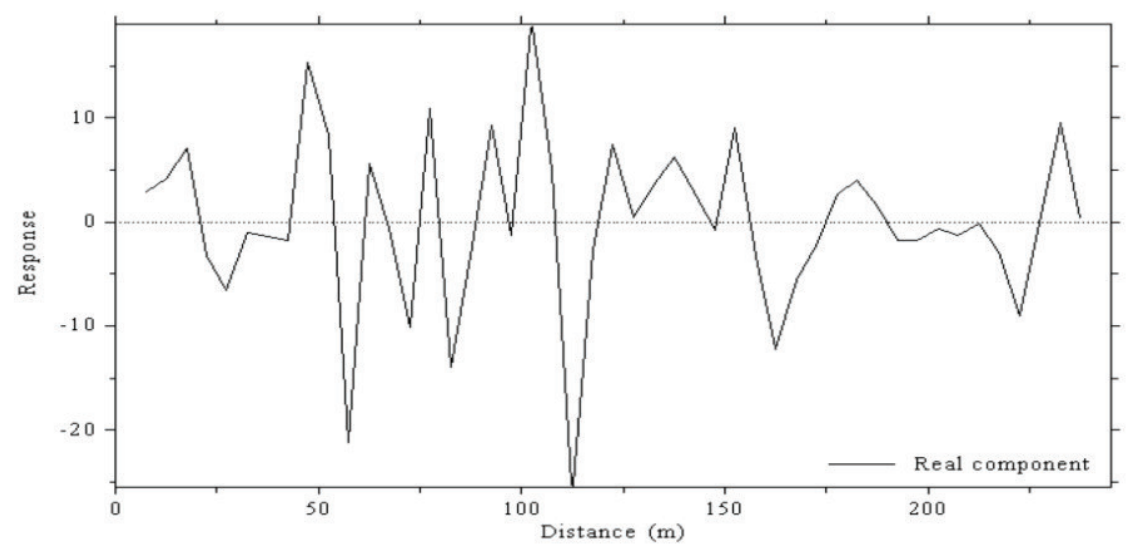

Karous-Hjelt filtering "Odo Abata, Ilora Profile 3 "
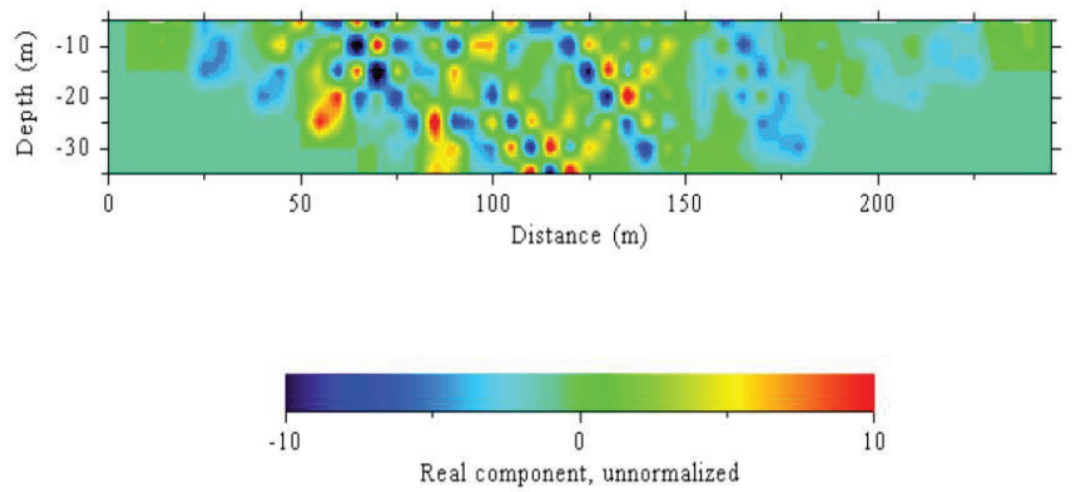

Fig. 10 :( a) Fraser filtering of Odo-Abata VLF profile 3 (b)Karous-Hjelt filtering of Odo-Abata VLF profile3 
Fraser filtering
"Odo Abata, Ilora Profile 4"

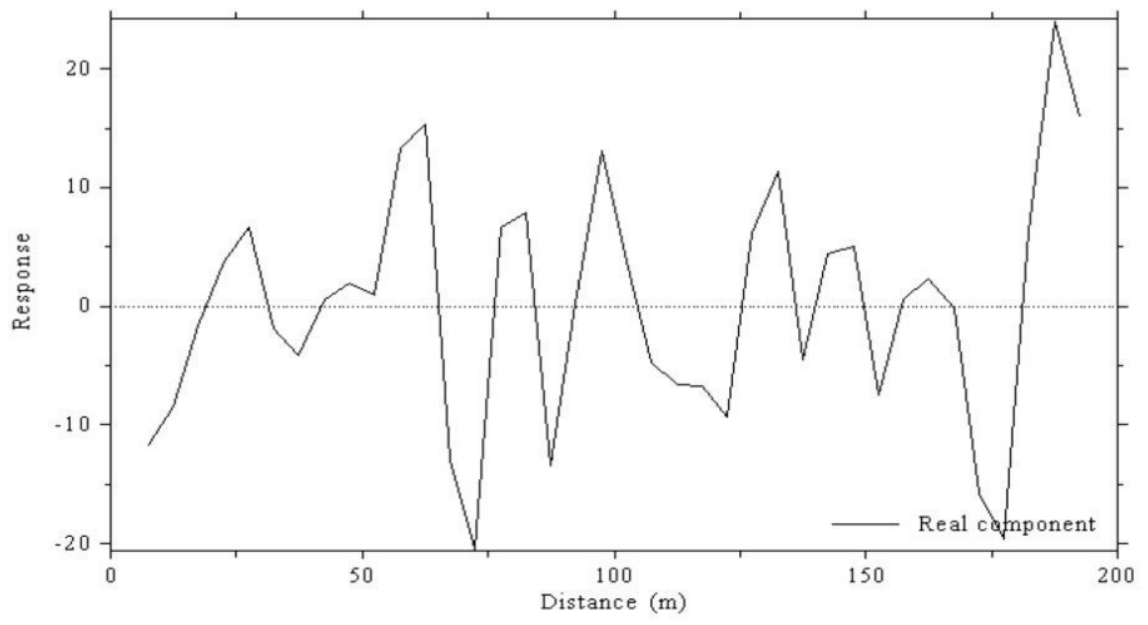

Karous-Hjelt filtering "Odo Abata, Ilora Profile 4"
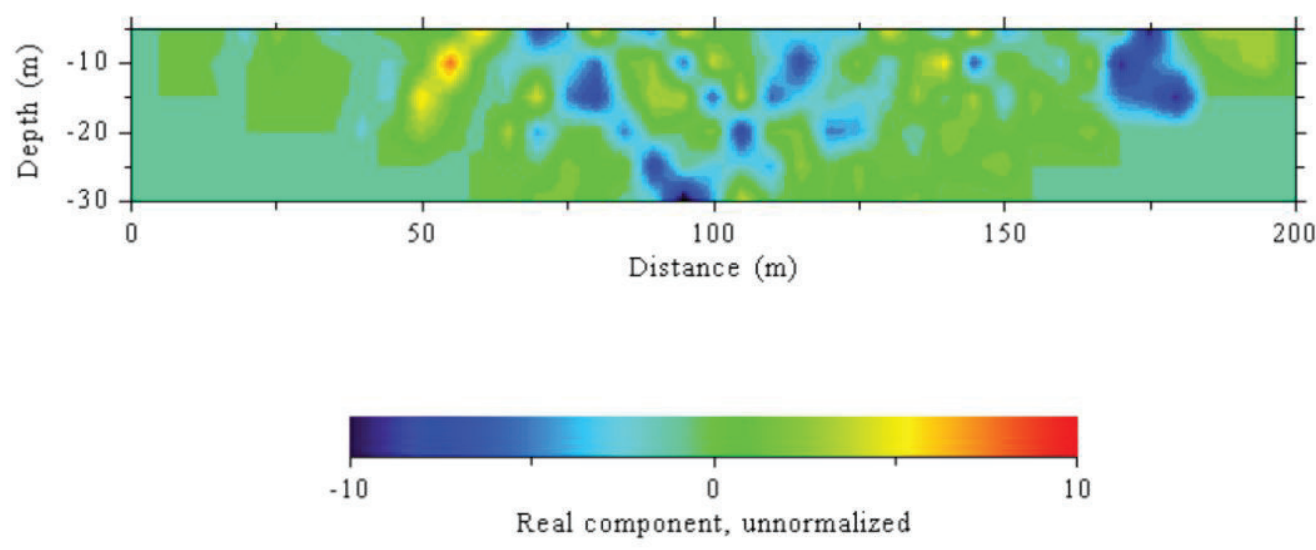

Fig.11 ( a) Fraser filtering of Odo-Abata VLF profile 4 (b)Karous-Hjelt filtering of Odo-Abata VLF profile 4 


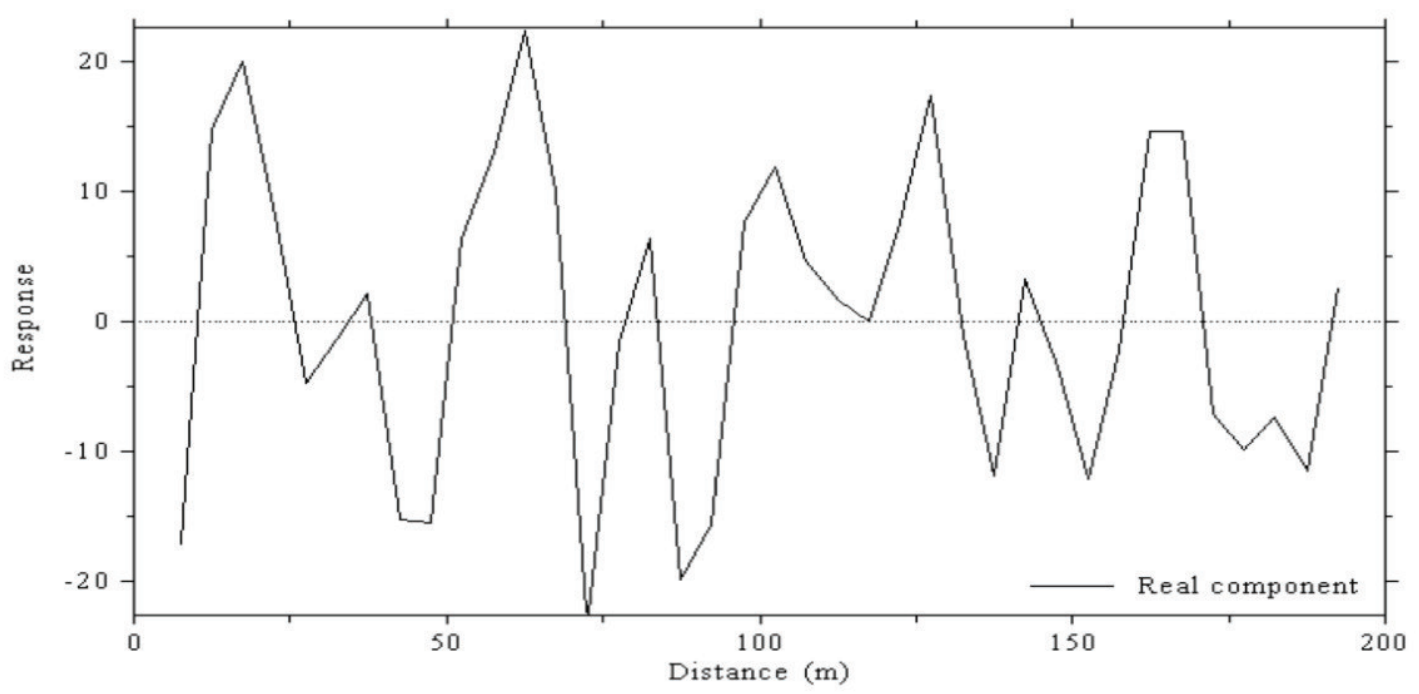

Karous-Hjelt filtering "Odo Abata, Ilora Profile 5 "
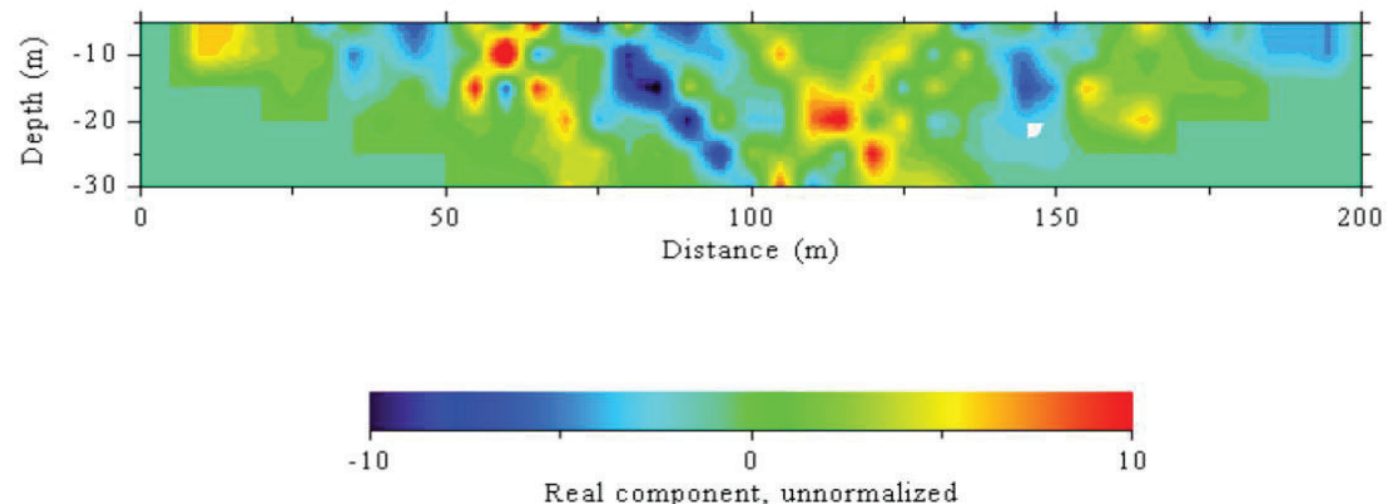

Fig. 12 :( a) Fraser filtering of Odo-Abata VLF profile 5

(b)Karous-Hjelt filtering of Odo-Abata VLF profile 5 
Fraser filtering
"Odo Abata, Ilora Profile 6"

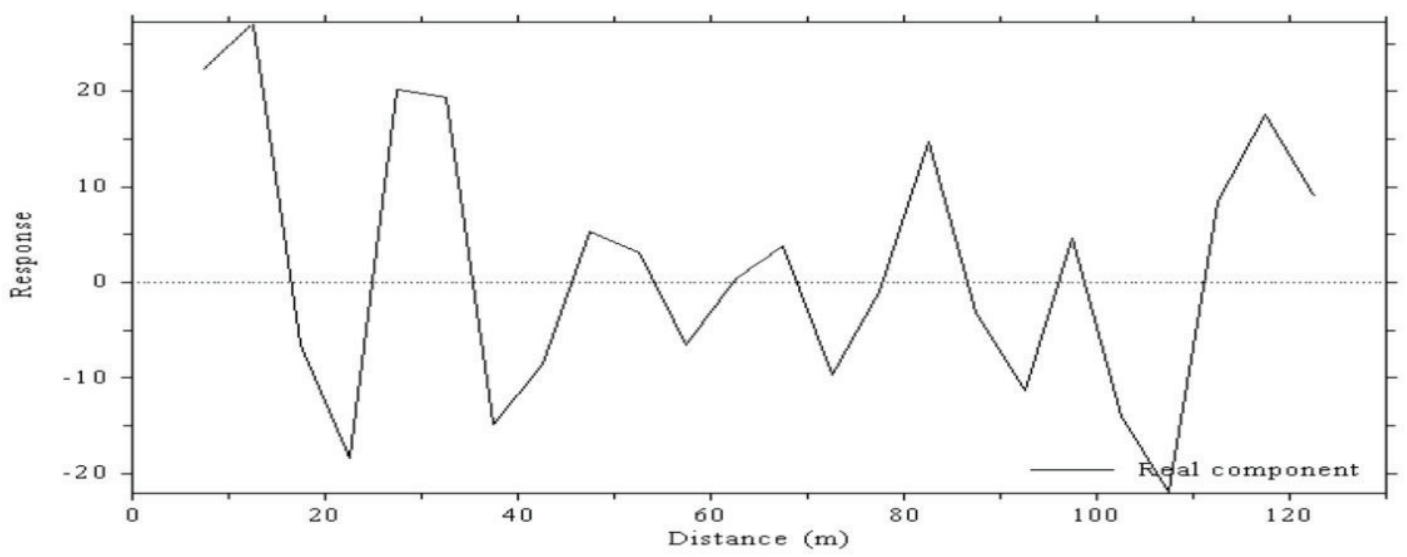

Karous-Hjelt filtering "Odo Abata, Hlora Profile 6 "
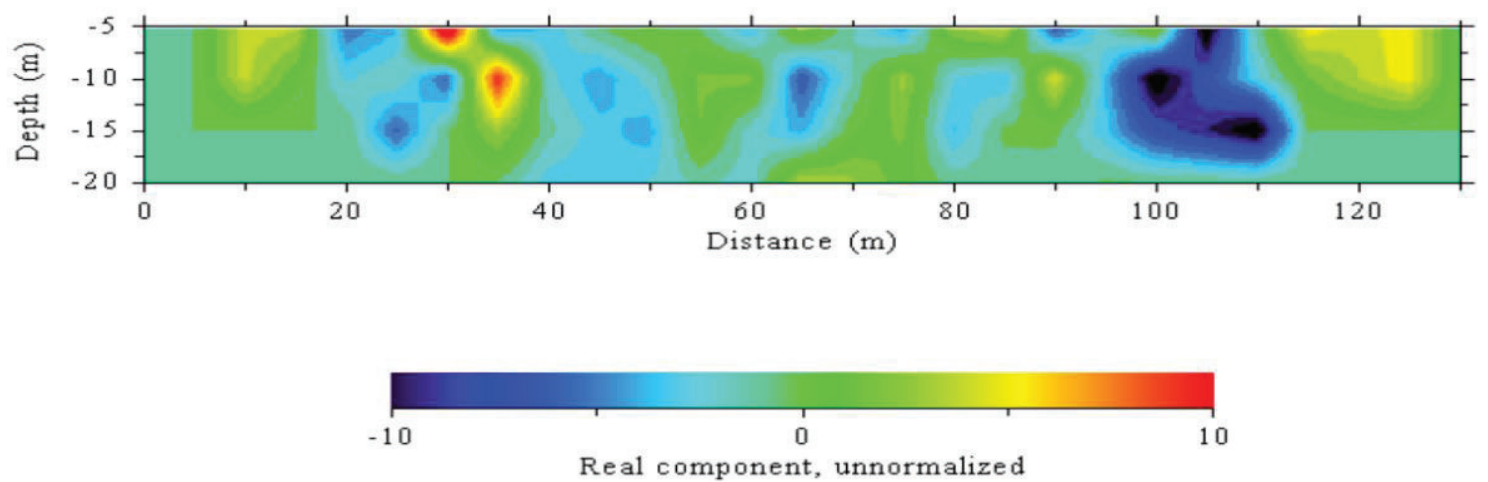

Fig.13 :( a) Fraser filtering of Odo-Abata VLF profile 6 (b)Karous-Hjelt filtering of Odo-Abata VLF profile6 
Fraser filtering
Abata, Ilora Profile 7 "

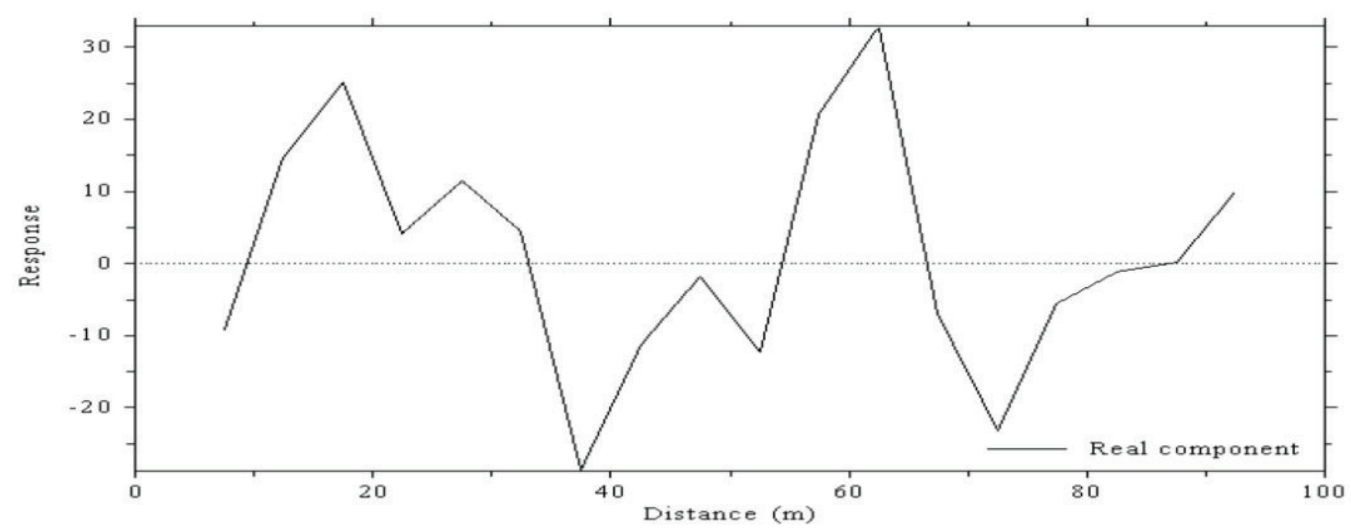

Karous-Hjelt filtering
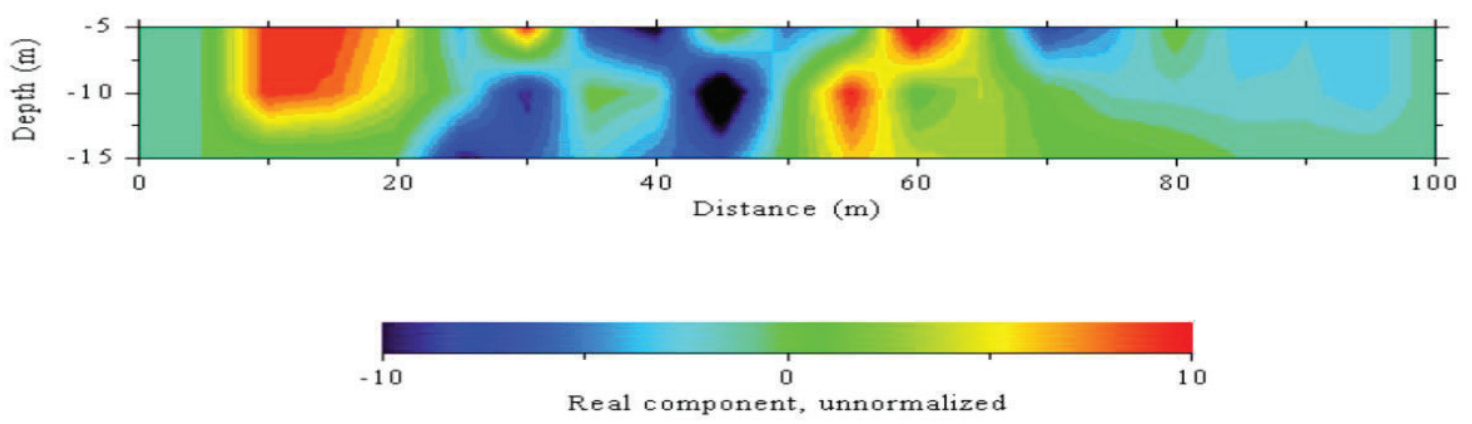

Fig.14 :( a) Fraser filtering of Odo-Abata VLFprofile 7

(b)Karous-Hjelt filtering of Odo-Abata VLF profile 
Fraser filtering

"Odo Abata, Ilora Profile 8 "

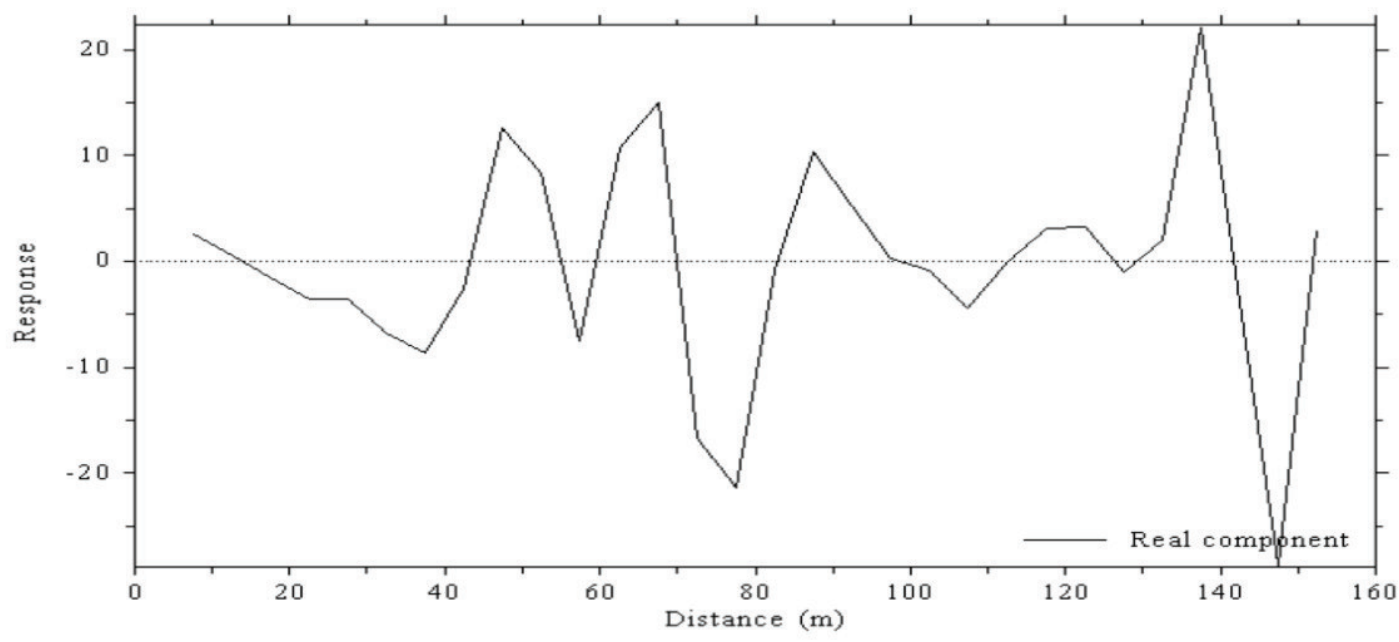

Karous-Hjelt filtering "Odo Abata, Ilora Profile 8 "

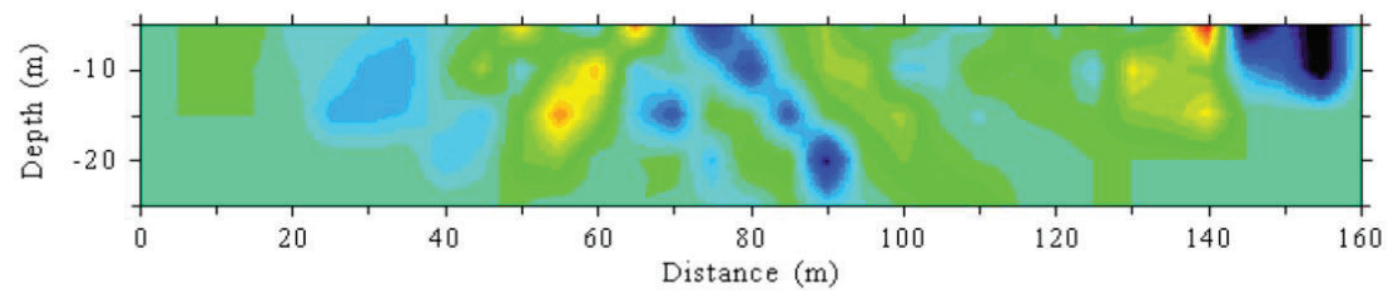

Real component, unnormalized

Fig. 15 :( a) Fraser filtering of Odo-Abata VLF profile 8

(b)Karous-Hjelt filtering of Odo-Abata VLF profile8 

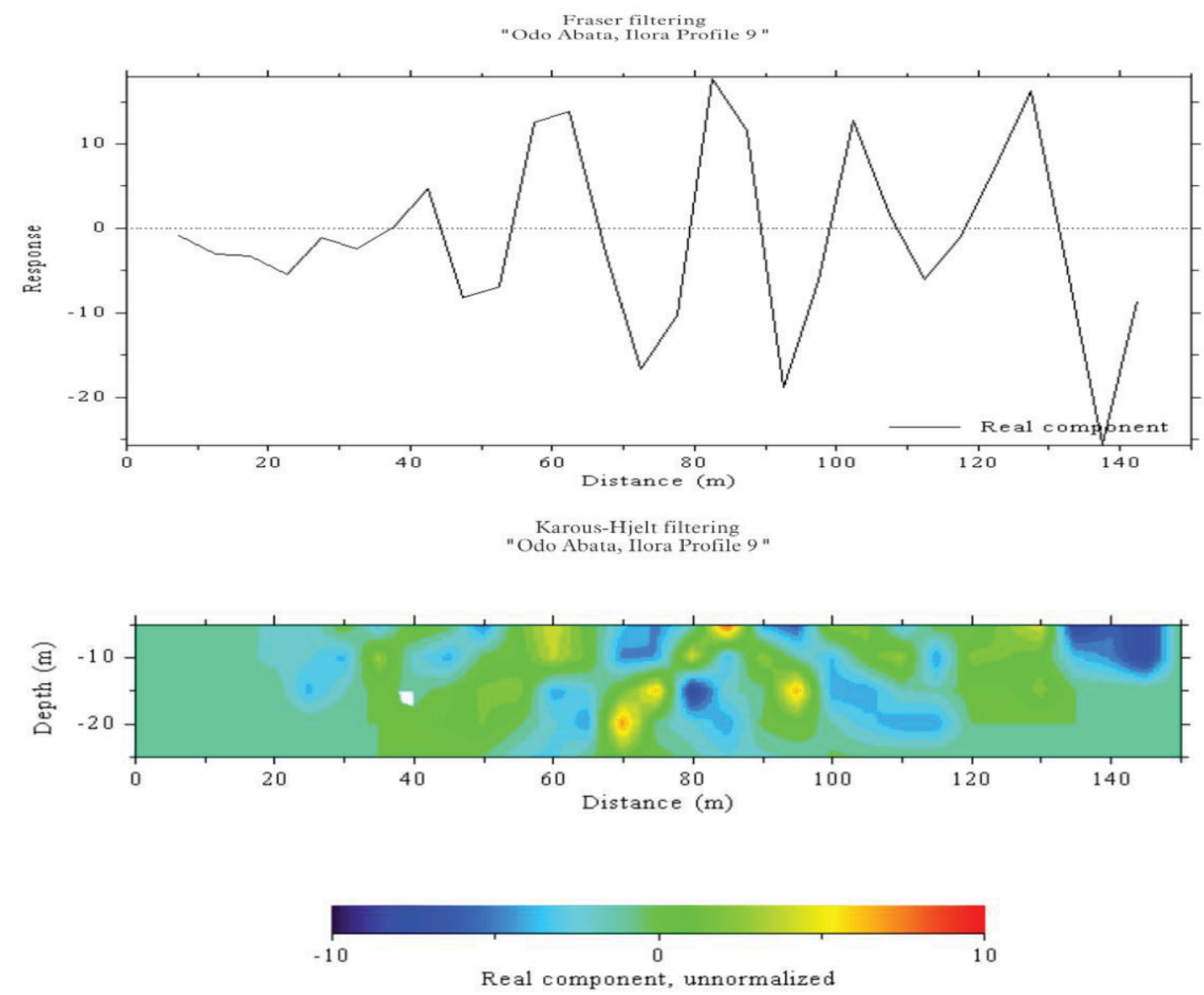

Fig.16:( a) Fraser filtering of Odo-Abata VLF profile 9 (Control profile) (b)Karous-Hjelt filtering of Odo-Abata VLF profile9 (Control profile)

LIME1 (2-D Resistivity Structure)

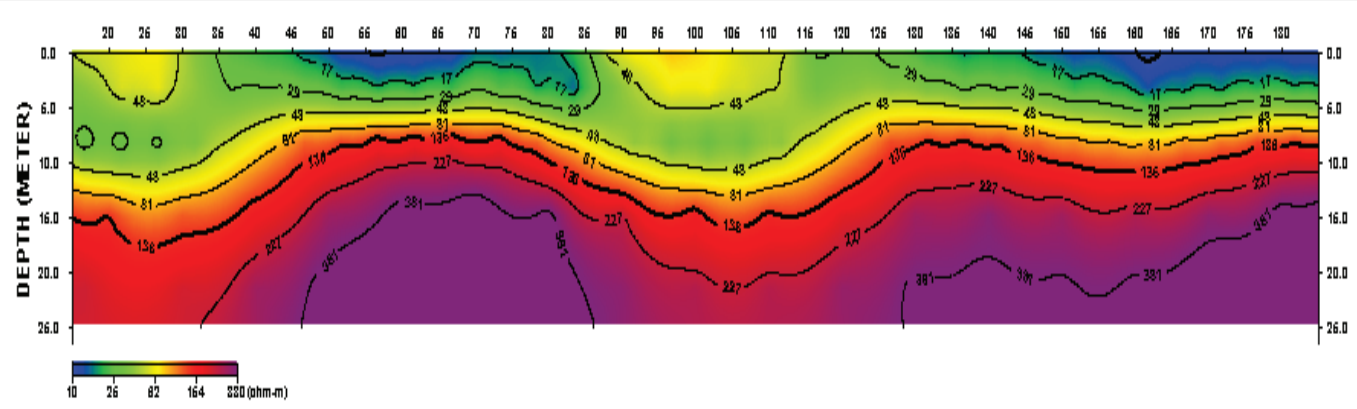

Fig17: Inverted section for Electrical Imaging profile1

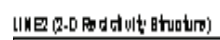

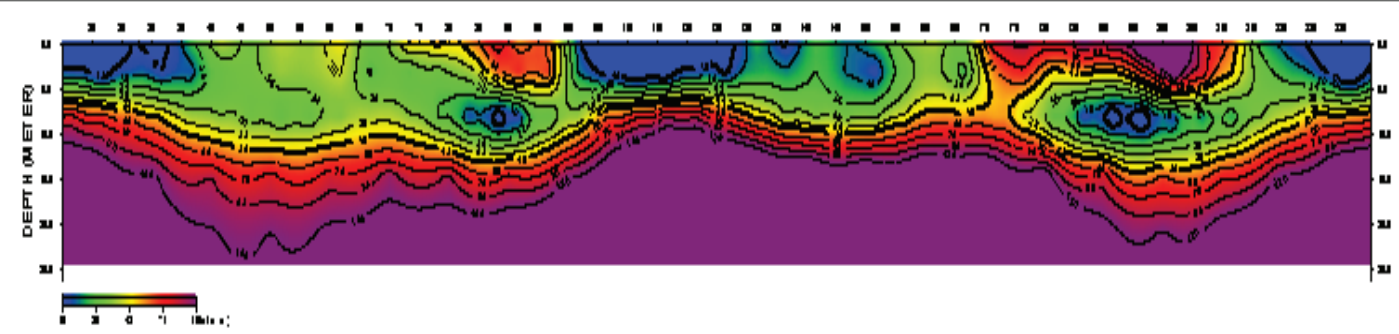

Fig. 18: Inverted section for Electrical Imaging profile 2 


\section{LINE 3 (2-D Resistivity Structure)}

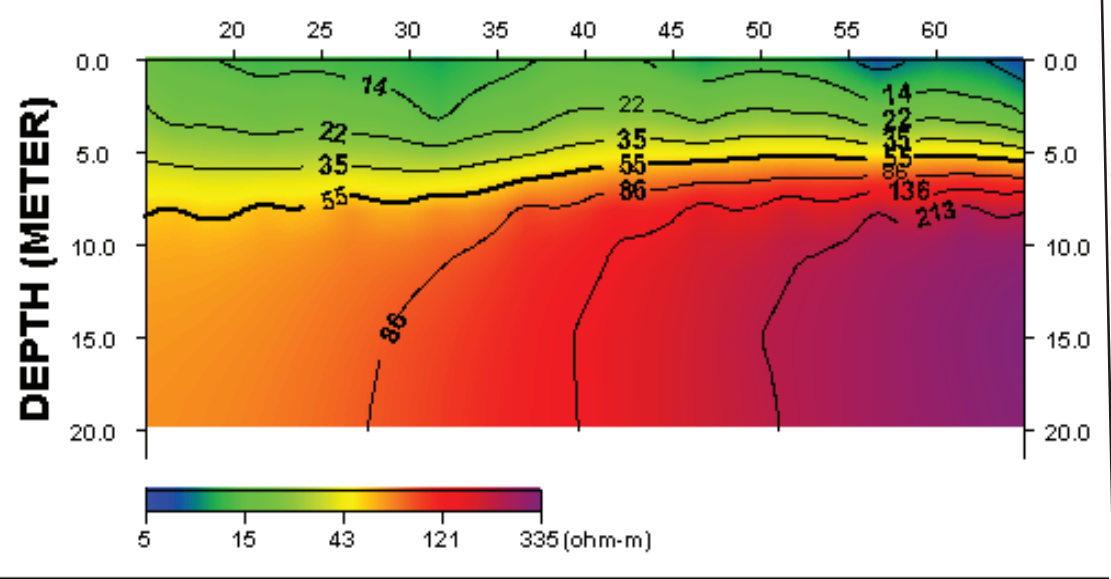

Fig 19: Inverted section for Electrical ImagingProfile3

\section{LINE4 (2-D Resistivity Structure)}

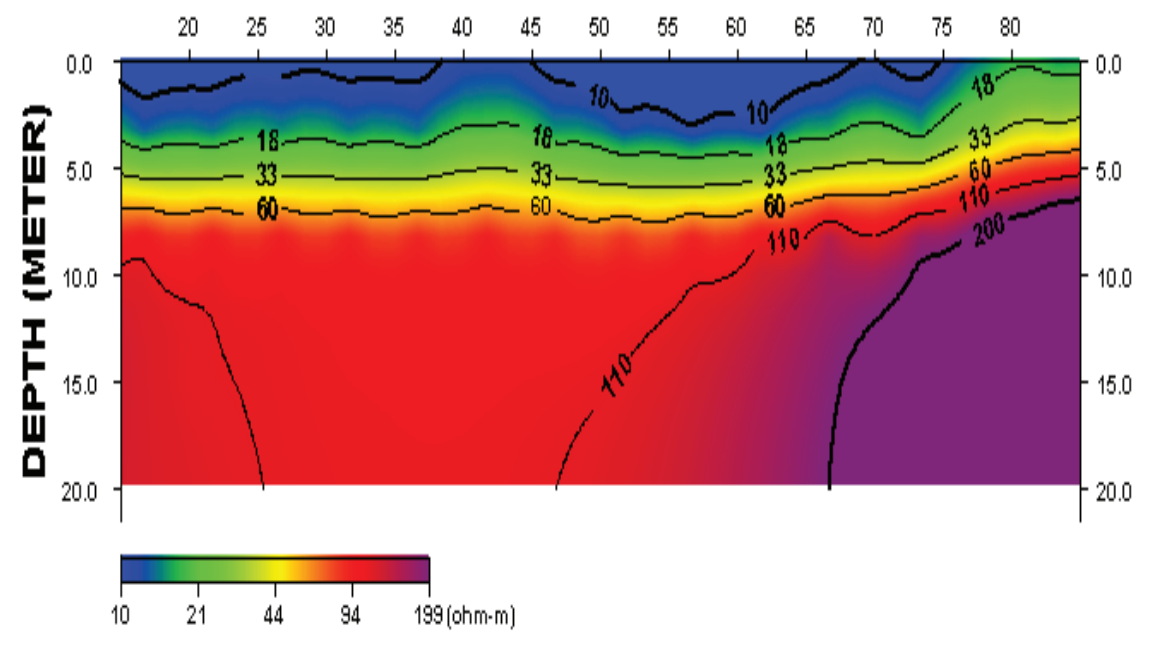

Fig 20: Inverted section for Electrical Imaging profile 4

\section{LINE5 (2-D Resistivity Structure)}

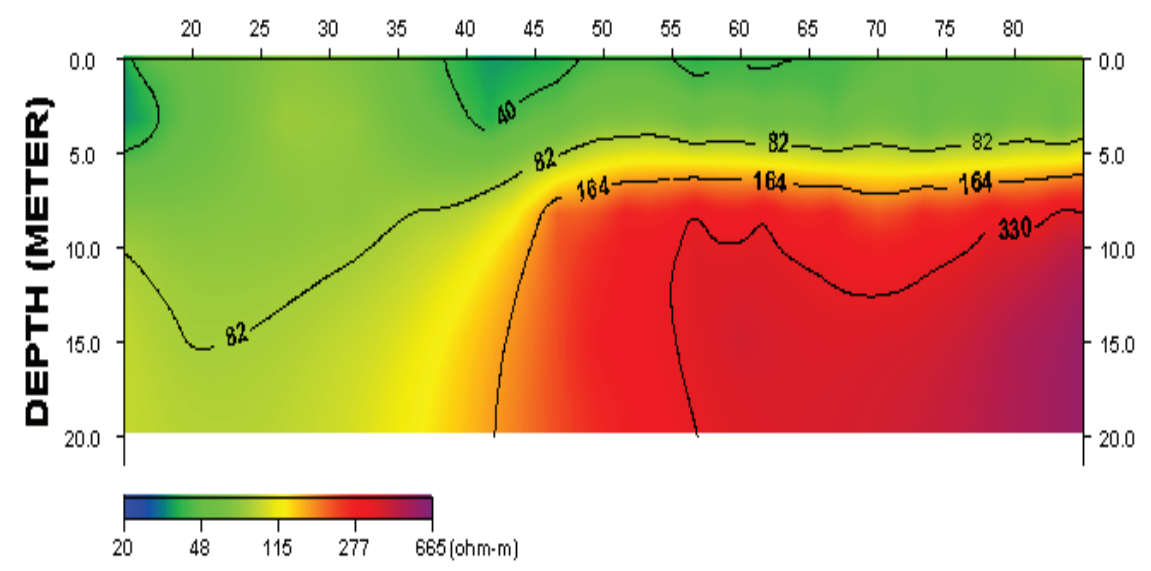

Fig. 21: Inverted section for Electrical Imaging profile 5 (control profile) 


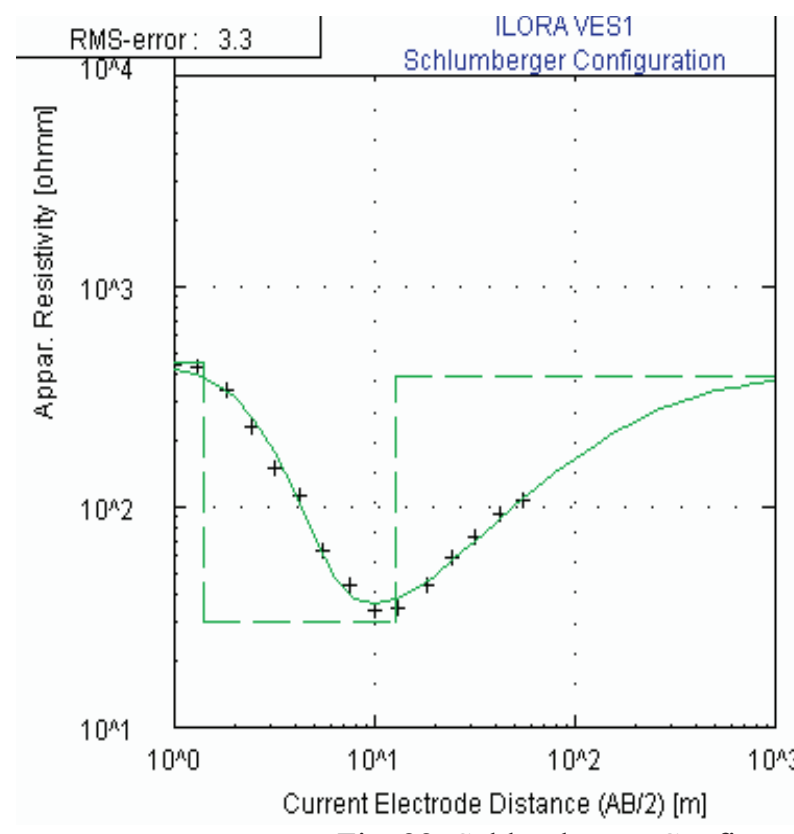

\begin{tabular}{|cccc} 
No & Res & Thick & Depth \\
\hdashline 1 & 448.6 & 1.4 & 1.4 \\
2 & 30.0 & 11.4 & 12.8 \\
3 & 394.8 & --- & --
\end{tabular}

Fig. 22: Schlumberger Configuration for VES 1

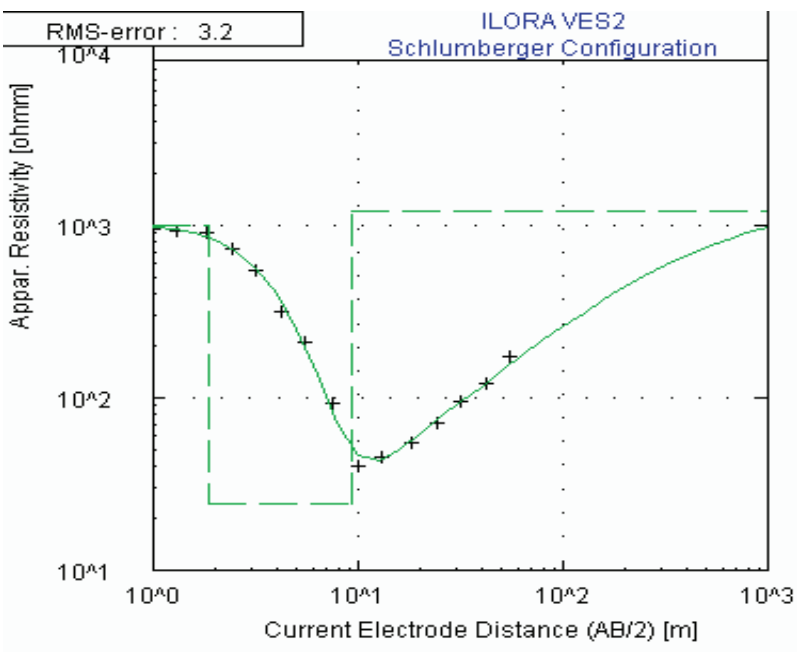

Fig. 23: Schlumberger Configuration for VES 2

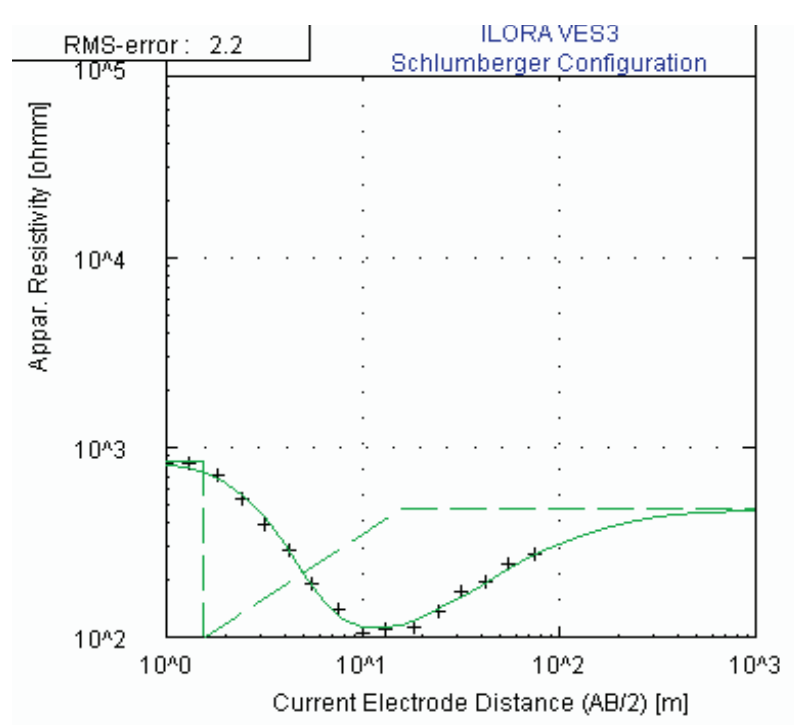

$$
\begin{array}{|cccc}
\text { No } & \text { Res } & \text { Thick } & \text { Depth } \\
\hdashline 1 & 850.0 & 1.5 & 1.5 \\
2 & 97.4 & 14.1 & 15.7 \\
3 & 471.4 & -.- & --
\end{array}
$$

Fig. 24: Schlumberger Configuration for VES 3 (Control) 